ISSN 2089-8673

Jurnal Nasional Pendidikan Teknik Informatika (JANAPATI)

Volume 2, Nomor 1, Maret 2013

\title{
PENGEMBANGAN MEDIA AUDIO-VISUAL PADA MATA DIKLAT \\ MENERAPKAN EFEK KHUSUS PADA OBJEK PRODUKSI \\ BERBASIS PROJECT BASED LEARNING UNTUK SISWA \\ KELAS XII SMK NEGERI 3 SINGARAJA
}

\section{Oleh}

\author{
Ketut Satria ${ }^{1}$, Made Windu Antara Kesiman, S.T., M.Sc. ${ }^{2}$, dan I Gede Mahendra \\ Darmawiguna, S.Kom., M.Sc. ${ }^{3}$ \\ Jurusan Pendidikan Teknik Informatika \\ e-mail: darkcommunity@yahoo.com ${ }^{1}$,dekndu@yahoo.com², \\ igd.mahendra.d@gmail.com ${ }^{3}$
}

\begin{abstract}
ABSTRAK
Penelitian ini bertujuan untuk: (1) mengembangkan media audio-visual pada mata diklat menerapkan efek khusus pada objek produksi berbasis project based learning untuk siswa kelas XII SMK Negeri 3 Singaraja ; dan (2) mengetahui respon siswa dan guru terhadap pengembangan media audio-visual pada mata diklat menerapkan efek khusus pada objek produksi berbasis project based learning untuk siswa kelas XII SMK Negeri 3 Singaraja.

Subyek penelitian adalah seluruh siswa kelas XI untuk program keahlian multimedia di SMK Negeri 3 Singaraja tahun pelajaran 2011/2012 sebanyak 29 orang. Penelitian yang dilakukan adalah penelitian pengembangan. Data yang dikumpulkan yaitu data respon siswa dan respon guru terhadap pengembangan media audio-visual pada mata diklat menerapkan efek khusus pada objek produksi berbasis project based learning dengan mengunakan angket. Data respon siswa dianalisis secara deskriptif.

Hasil penelitian ini menujukkan bahwa respon siswa terhadap pengembangan media audio-visual pada mata diklat menerapkan efek khusus pada objek produksi berbasis project based learning tersebar pada kategori sangat positif $0 \%$, positif 86,21 $\%$, ragu-ragu $13,79 \%$, negatif $0 \%$ dan sangat negatif $0 \%$. Rata-rata skor respon siswa yaitu 52.86 sehingga respon siswa dikategorikan positif. Sedangkan untuk rata-rata skor respon guru yaitu 51, sehingga respon guru dikategorikan positif. Maka jika digabungkan antara respon siswa dan respon guru tersebar pada kategori positif.
\end{abstract}

Kata-kata kunci: media audio visual, project based learning, menerapkan efek khusus pada objek produksi. 
ISSN 2089-8673

Jurnal Nasional Pendidikan Teknik Informatika (JANAPATI)

Volume 2, Nomor 1, Maret 2013

\begin{abstract}
This research was aimed at: (1) developing audio-visual media in a course on applying special effects to the production object based on project based learning for XII students of SMK Negeri 3 Singaraja; and (2) studying the response of the students and teachers to the development of audio-visual media in a course on applying special effects to the production object based on project based learning for XII students of SMK Negeri 3 Singaraja.

The subjects of the study were 29 students in grade XI of multimedia program of SMK Negeri 3 Singaraja in the academic year 2011/2012. This research was a research and development. The data collected were the students and teacherôs responses in a course on applying special effects to the production object based on project based learning for XII students of SMK Negeri 3 Singaraja by using questionnaires. The responsed data of students and teachers were analyzed descriptively.

The results of this study show that students responses to the development of audio-visual media in a course on applying special effects to the production object based on project based learning for XII students of SMK Negeri 3 Singaraja was very positive on the category of $0 \%$, positive $86.21 \%, 13.79 \%$ uncertain, negative $0 \%$ and $0 \%$ very negative. The average score was 52.86 . While the average score for teacherôs responses was 51. Thus, the students and teacherôs responses was categorized as positive.
\end{abstract}

Key words: audio visual media, project based learning, applying special effects to the production object.

\title{
I. Pendahuluan
}

SMK Negeri 3 Singaraja adalah Rintisan Sekolah Bertaraf Internasional (RSBI) yang telah mendapatkan sertifikat ISO 9001:2008 yang merupakan model untuk sistem manajemen mutu dalam perancangan atau pengembangan produk, produk perakitan demi meningkatkan mutu pendidikan yang mampu bersaing dan mampu mengangkat nama baik Bangsa dan Negara khususnya dibidang pendidikan. Standar ISO 9001:2008 yang digunakan di SMK Negeri 3 Singaraja pun melatih mereka untuk berkerja secara terstrukur dan rapih.

Salah satu mata diklat yang diajarkan di Sekolah Menengah Kejuruan bidang studi keahlian Teknologi Informasi dan Komunikasi, program studi keahlian Teknik Komputer dan Informatika, kompetensi keahlian Multimedia SMK Negeri 3 Singaraja adalah mata diklat Menerapkan Efek Khusus Pada Objek Produksi. Menurut silabus mata diklat Menerapkan Efek Khusus Pada Objek Produksi siswa diharapkan mampu 
ISSN 2089-8673

Jurnal Nasional Pendidikan Teknik Informatika (JANAPATI)

Volume 2, Nomor 1, Maret 2013

mengidentifikasikan materi penunjang efek khusus misalnya dengan mencermati penggunaan software efek visual dan nenjelaskan penggunaan efek visual. Kemudian siswa diharapkan mampu menginstallasi software efekkhusus dan kompetensi yang paling penting dikuasai oleh siswa adalah mampu membuat efek khusus pada obyek produksi.

Berdasarkan hasil observasi yang dilakukan di kelas SMK Negeri 3 Singaraja pada mata diklat Menerapkan Efek Khusus Pada Objek Produksi, proses pengajaran cenderung berpusat pada guru (teacher centered). Konsep yang diajarkan guru hanya digambarkan di kertas lampiran dan disampaikan secara lisan. Bahan tayangan dalam penyajian materi pun terbatas. Dalam hal ini guru berperan mentransfer materi namun terkadang kurang melibatkan keaktifan siswa, sehingga siswa hanya menerima secara abstrak dan sibuk mencatat materi yang disampaikan guru, kesulitan guru memvisualisasikan contoh yang bersifat abstrak.

Karena alasan tersebut di atas, peneliti menyajikan sebuah media audio visual Berbasis Proyek (Project based learning). Pembelajaran berbasis proyek pun mampu membuat suasana kelas menyenangkan, sehingga peserta didik maupun instruktur menikmatinya. Guru hanya sebagai fasilitator, mengevaluasi produk hasil kerja peserta didik yang ditampilkan dalam hasil proyek yang dikerjakan.

Adapun yang melatarbelakangi pemilihan model Pembelajaran Berbasis Proyek (Project based learning) dalam penelitian ini adalah dari segi faktor siswa, sampel dalam penelitian ini adalah siswa SMK Negeri 3 Singaraja.

Berdasarkan deskripsi program pendidikan sekolah menengah kejuruan bidang studi keahlian teknologi informasi dan komunikasi program studi keahlian teknik komputer dan informatika kompetensi keahlian multimedia, mata diklat menerapkan efek khusus pada objek produksi adalah mata diklat yang didapatkan oleh kelas XII pada kompetensi keahlian multimedia. Mata diklat ini mempelajari tentang pembuatan berbagai macam objek produksi seperti: iklan, video klip, video pembelajaran, animasi, serta media informasi.

Menurut silabus mata diklat Menerapkan Efek Khusus Pada Objek Produksi siswa diharapkan mampu mengidentifikasikan materi penunjang efek khusus misalnya dengan 
ISSN 2089-8673

Jurnal Nasional Pendidikan Teknik Informatika (JANAPATI)

Volume 2, Nomor 1, Maret 2013

mencermati penggunaan software efek visual dan nenjelaskan penggunaan efek visual. Kemudian siswa diharapkan mampu menginstallasi software efek khusus dan kompetensi yang paling penting dikuasai oleh siswa adalah mampu membuat efek khusus pada obyek produksi.

Mata diklat menerapkan efek khusus pada objek produksi memanfaatkan perangkat lunak seperti: adobe after effect, adobe premiere pro, adobe photoshop, pinnacle studio 12 , dan sony vegas. Perangkat lunak tersebut akan saling berintegrasi untuk menghasilkan effect yang lebih menarik.

\section{Metodologi}

Media audiovisual adalah media instruksional modern yang sesuai dengan perkembangan jaman (kemajuan IPTEK) meliputi media yang dapat dilihat, didengar dan yang dapat dilihat dan didengar bagi penggunanya untuk mengkomunikasikan dan mendokumentasikan informasi yang didapatkan.

Menurut Munadi (2008:113-114) memaparkan bahwa:

Media audiovisual ini dapat dibagi menjadi dua jenis. Jenis pertama adalah, dilengkapi fungsi peralatan suara dan gambar dalam kesatuan unit, dinamakan media audio-visual murni, seperti film gerak (movie) bersuara, televisi dan video. Jenis kedua adalah media audio visual tidak murni yakni apa yang kita kenal dengan slide, opaque, OHP dan peralatan visual lainnya bila diberi unsur suara dari rekaman kaset yang dimanfaatkan secara bersamaan.

Model pengembangan yang digunakan yaitu model pengembangan Dick and Carey. Penulis menggunakan model pengembangan ini dikarenakan model ini digunakan pada penelitian pengembangan pendidikan. Langkah pada model Dick and Carey menunjukan hubungan yang sangat jelas, dan tidak terputus antara langkah yang satu dengan yang lainya. Dengan kata lain, sistem yang terdapat pada Dick and Carey sangat ringkas, namun isinya padat dan jelas dari satu urutan keurutan berikutnya (Dadang Supriatna, 2007). Dan pada perancangan suatu penelitian pengembangan pendidikan, penulis beranggapan model Dick and Carey adalah model pengembangan yang tepat. Selain itu penulis juga menggabungkan model pengembangan Dick and Carey ini dengan model pengembangan waterfall. Penulis menggunakan waterfall 
ISSN 2089-8673

Jurnal Nasional Pendidikan Teknik Informatika (JANAPATI)

Volume 2, Nomor 1, Maret 2013

dikarenakan penulis beranggapan bahwa waterfall adalah model yang tepat untuk mengembangkan suatu software yang berbasis pendidikan dengan menggabungkannya bersama model Dick and Carey. Namun pada penelitian ini, penulis tidak sampai pada tahap pengukuran hasil pembelajaran, hanya pada tahap pengembangan dan menganalisis respon siswa dan guru terhadap media audio-visual Pada Mata Diklat Menerapkan Efek Khusus Pada Objek Produksi Berbasis Project based learning Untuk Siswa Kelas XII SMK Negeri 3 Singaraja yang dikembangkan.

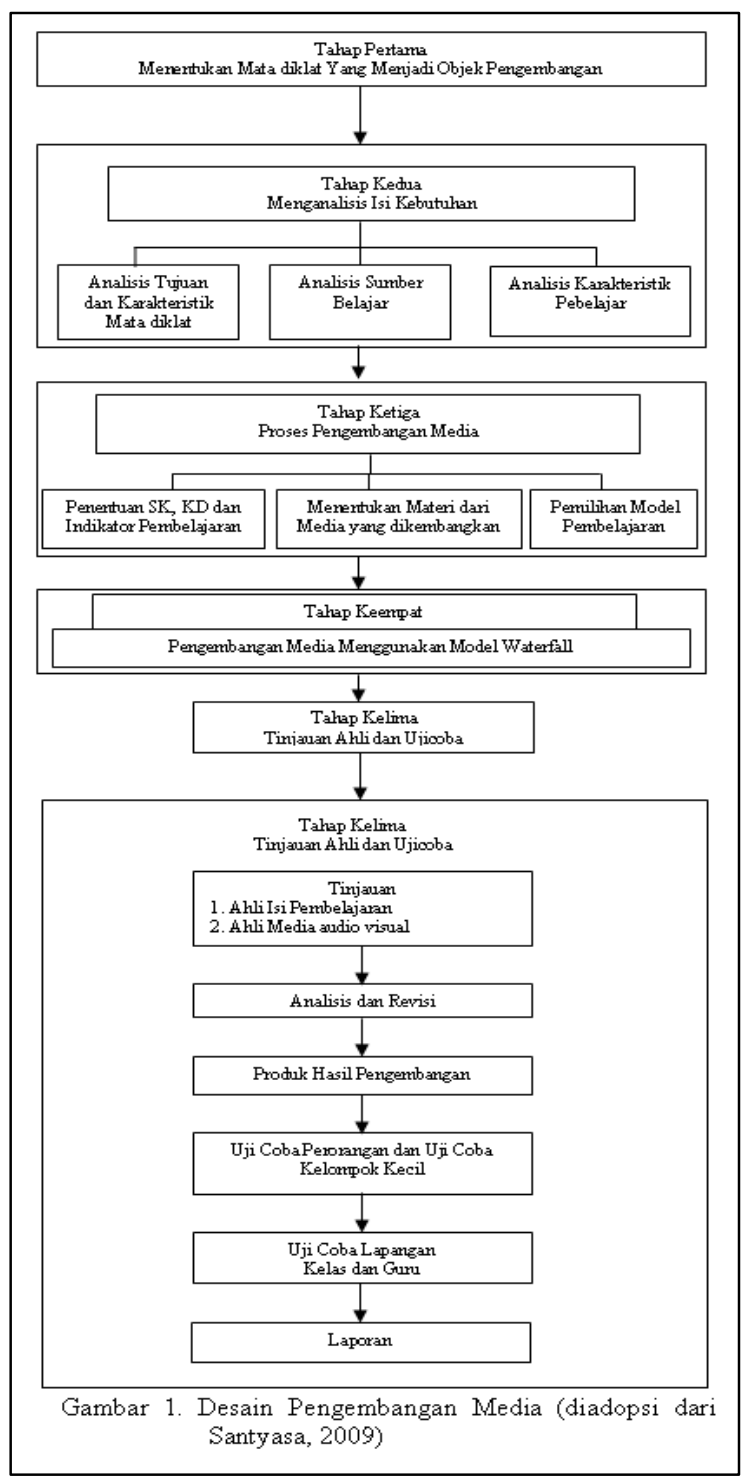


ISSN 2089-8673

Jurnal Nasional Pendidikan Teknik Informatika (JANAPATI)

Volume 2, Nomor 1, Maret 2013

Rancangan sistem dari Media audio visual pada Mata diklat Menerapkan Efek Khusus Pada Objek Produksi ini dapat digambarkan dengan menggunakan Data Flow Diagram (DFD). Hubungan antara sistem dengan entitas pada Media Audio Visual Menerapkan Efek Khusus Pada Objek Produksi Berbasis Project based learning ini dapat digambarkan dengan DFD (Data Flow Diagram) sebagai berikut.

Rancangan antarmuka merupakan rancangan awal dari pembuatan form-form yang ada pada media audio visual pada mata diklat Menerapkan Efek Khusus Pada Objek Produksi. Berikut adalah contoh rancangan antarmuka media audio visual.

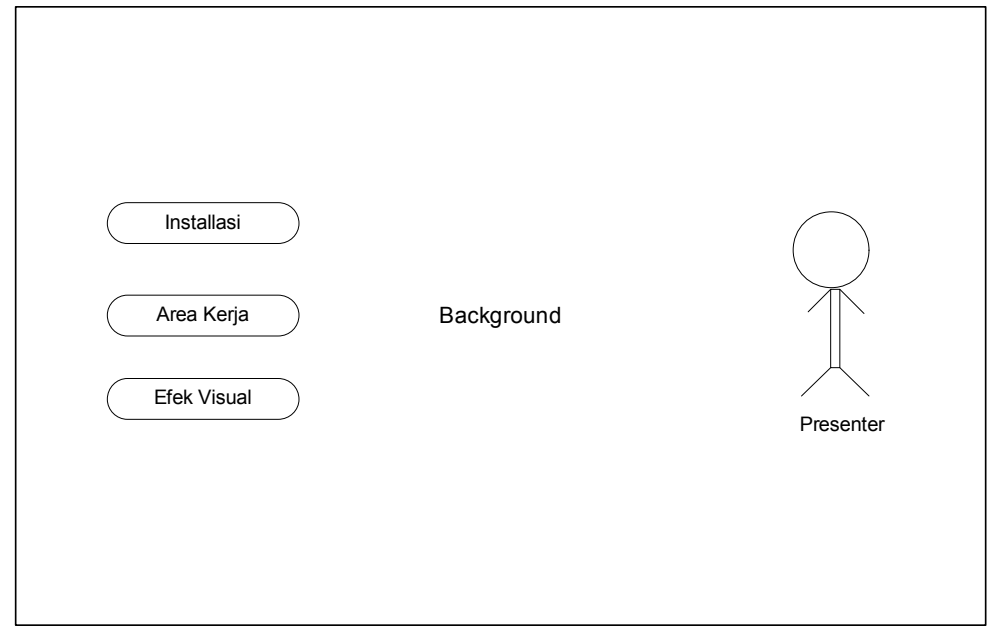

Gambar 2 Rancangan Antarmuka Form Utama

Uji coba produk dalam penelitian pengembangan ini terdiri atas: (1) rancangan uji coba, (2) subyek coba, (3) jenis data, (4) instrumen pengumpulan data, dan (5) teknik analisis data. Instrumen dan metode evaluasi yang digunakan untuk tinjauan ahli isi, ahli media, dan ahli desain media pembelajaran yaitu berupa angket.

Angket respon siswa validitasnya diuji dengan expert judgement dengan menggunakan skala likert 5. Data respon siswa dan respon guru dianalis dengan menggunakan statistik deskriptif, dan penyimpulannya didasarkan atas Mean Ideal (Mi) dan simpangan baku ideal ( $\mathrm{Si})$.

Respon siswa dan respon guru digali menggunakan kuesioner dengan skala likert 5 (nilai 1 sampai 5) yang dianalisis secara deskriptif. Konversi tingkat respon siswa dapat dilihat pada tabel 1. 
ISSN 2089-8673

Jurnal Nasional Pendidikan Teknik Informatika (JANAPATI)

Volume 2, Nomor 1, Maret 2013

Tabel 1. Konversi Kualifikasi Respon Siswa

\begin{tabular}{|c|c|}
\hline \multicolumn{1}{|c|}{ Rentangan Nilai } & Kualifikasi \\
\hline $\mathrm{M}_{\mathrm{i}}+1,5 \mathrm{~S}_{\mathrm{i}} \leq \mathrm{X}$ & Sangat Positif \\
\hline $\mathrm{M}_{\mathrm{i}}+0,5 \mathrm{~S}_{\mathrm{i}} \leq \mathrm{X}<\mathrm{M}_{\mathrm{i}}+1,5 \mathrm{~S}_{\mathrm{i}}$ & Positif \\
\hline $\mathrm{M}_{\mathrm{i}} \mathrm{I} \quad 0,5 \mathrm{~S}_{\mathrm{i}} \leq \mathrm{X}<\mathrm{M}_{\mathrm{i}}+0,5 \mathrm{~S}_{\mathrm{i}}$ & Ragu-ragu \\
\hline $\mathrm{M}_{\mathrm{i}} \mathrm{i} 1,5 \mathrm{~S}_{\mathrm{i}} \leq \mathrm{X}<\mathrm{M}_{\mathrm{i}} \ddot{i} 0,5 \mathrm{~S}_{\mathrm{i}}$ & Negatif \\
\hline $\mathrm{X}<\mathrm{M}_{\mathrm{i}} \ddot{I} 1,5 \mathrm{~S}_{\mathrm{i}}$ & Sangat Negatif \\
\hline
\end{tabular}

$M_{i}=1 / 2$ (skor tertinggi ideal + skor terendah ideal)

$\mathrm{S}_{\mathrm{i}}=1 / 6$ (skor tertinggi ideal - skor terendah ideal) 
ISSN 2089-8673

Jurnal Nasional Pendidikan Teknik Informatika (JANAPATI)

Volume 2, Nomor 1, Maret 2013

Berikut merupakan hasil uji coba media audio visual pada mata diklat menerapkan efek khusus pada objek produksi berbasis project based learning.

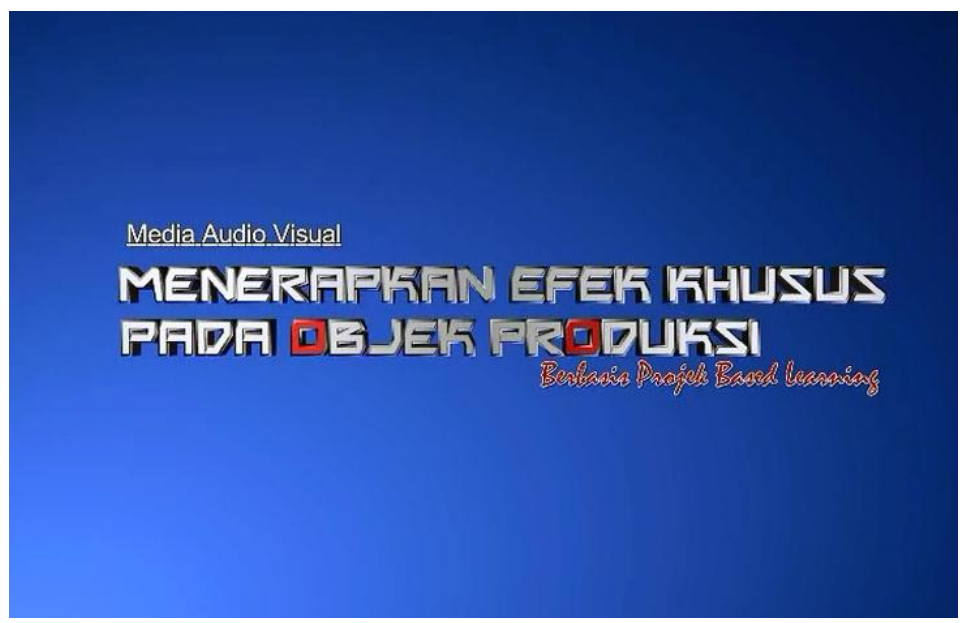

Gambar 3. Opening

\section{Tujuan Pembelajaran}

Setelah menyimak video ini guru dan siswa diharapkan mampu:

1.1 Mengenal perangkat lunak pembuatan efek khusus pada digital editing.

1.2 Mengetahui hasil efek visual untuk produksi digital editing.

1.3 Menjelaskan fungsi software efek visual pada produksi digital editing.

1.4 Mengetahui penggunaan efek visual pada produksi digital editing.

1.5 Mengenal bahan penunjang efek khusus dalam digital editing.

1.6 Mengetahui materi penunjang efek khusus pada digital editing.

Gambar 4. Menu Tujuan 
ISSN 2089-8673

Jurnal Nasional Pendidikan Teknik Informatika (JANAPATI)

Volume 2, Nomor 1, Maret 2013

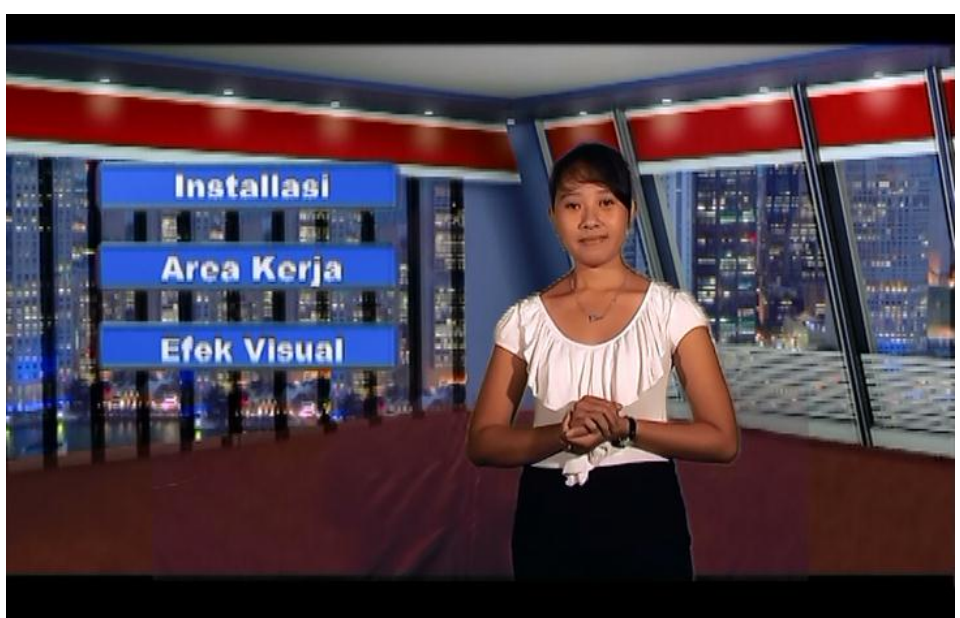

Gambar 5. Menu Utama 
ISSN 2089-8673

Jurnal Nasional Pendidikan Teknik Informatika (JANAPATI)

Volume 2, Nomor 1, Maret 2013

\section{Pembahasan}

Permasalahan yang paling menonjol dirasakan adalah keterbatasan media audio visual yang menarik dan sesuai untuk mata diklat Menerapkan Efek Khusus Pada Objek Produksi. Begitu juga dari hasil wawancara dengan siswa yang menyebutkan spesifikasi komputer untuk mengoperasikan software Menerapkan Efek Khusus Pada Objek Produksi masih kurang memadai karena sering terjadi hang pada saat siswa mengerjakan tugas dengan efekefek tertentu.

Hal ini menyebabkan sangat diperlukan pengembangan media audio visual. Penggunaan media audio visual berbasis project based learning dalam proses belajar mengajar dapat meningkatkan efisiensi, meningkatkan motivasi, memfasilitasi belajar aktif, memfasilitasi belajar eksperimental, konsisten dengan belajar yang berpusat pada siswa dan memandu untuk belajar lebih baik.

Dari hasil wawancara dengan guru mata diklat Menerapkan Efek Khusus Pada Objek Produksi, tujuan dari mata diklat Menerapkan Efek Khusus Pada Objek Produksi yaitu agar siswa mampu mempersiapkan software Menerapkan Efek Khusus Pada Objek Produksi, mampu mengenali serta menggunakan software Menerapkan Efek Khusus Pada Objek Produksi, melakukan pembuatan animasi serta efek khusus yang menarik, dan mampu mengintegrasikan animasi tersebut ke dalam sebuah movie. Karakteristik dari isi mata diklat yaitu lebih mengarah ke praktek untuk melakukan pembuatan efek yang menarik, pembuatana animasi objek dan mengubah animasi ke dalam bentuk movie.

Untuk mengetahui karakteristik pebelajar penulis melakukan wawancara dengan beberapa siswa tentang pelajaran Menerapkan Efek Khusus Pada Objek Produksi dan penyebaran angket karakteristik pebelajar. Dari hasil angket dan wawancara ini didapat informasi bahwa siswa sangat mendukung pengembangan media audio visual berbasis project based learning untuk mata diklat Menerapkan Efek Khusus Pada Objek Produksi dan sangat tertarik dengan bantuan ilustrasi video dan animasi untuk memahami lebih jauh tentang pembuatan efek yang menarik dalam mata diklat Menerapkan Efek Khusus Pada Objek Produksi.

Indikator yang dirumuskan terdapat di Silabus (lampiran 10). Menu yang dibuat pada media audio visual ini berdasarkan jumlah kompetensi dasar yang ada yaitu (1) 
ISSN 2089-8673

Jurnal Nasional Pendidikan Teknik Informatika (JANAPATI)

Volume 2, Nomor 1, Maret 2013

Mempersiapkan software Menerapkan Efek Khusus Pada Objek Produksi yaitu software Adobe After Effect yang akan diulas pada bagian installasi, (2) Mengenali area kerja dan interface, serta membuat, membuka, menyimpan file dalam software Adobe After Effect yang akan dibahas pada bagian area kerja, (3) Melakukan pembuatan animasi [dasar] After Effect yang akan dibahas pada bagian efek khusus yang terdiri dari pembuatan opening sederhana, motoracer, dan fido dido.

Media audio visual ini dibuat dengan menggunakan Pinnacle Studio 12, serta beberapa software pendukung seperti Ulead Photo Impact 10, Macromedia Fireworks 8, dan Photoshop untuk membuat dan mengedit gambar, Cool Edit Pro 2 untuk pengolahan suara, dan Adobe Premiere Pro 1.5, Adobe After Effect 6.5 dan Sony Vegas 7 untuk mengedit video.

Untuk Mengetahui apakah pengembangan media audio visual pada mata diklat Menerapkan Efek Khusus Pada Objek Produksi telah sesuai dengan tahapan yang ada, maka dilakukan diuji coba berdasarkan kasus yang ada.

Tahap terakhir dari pengembangan media media audio visual berbasis project based learning adalah review dari para ahli. Pada ahli Isi Pembelajaran dan yang dilibatkan adalah guru mata diklat Menerapkan Efek Khusus Pada Objek Produksi, ahli media dan ahli desain pembelajaran merupakan dosen Pendidikan Teknik Informatika yaitu dosen pembimbing I sebagai ahli media pembelajaran dan dosen pembimbing II sebagai desain media pembelajaran. Pada uji perorangan dan kelompok kecil media ini melibatkan enam orang siswa homogen dari kelas XII Multimedia SMK N 3 Singaraja. Pada saat uji coba lapangan melibatkan 29 orang siswa kelas XI Multimedia.

Respon siswa terhadap pengembangan media audio visual multimedia Menerapkan Efek Khusus Pada Objek Produksi dikumpulkan dengan menggunakan angket respon siswa. Berdasarkan hasil analisis skor respon siswa (terlampir pada lampiran 13) didapatkan kategori yang telah ditetapkan disajikan pada tabel 3.

Tabel 3 Konversi Respon Siswa

\begin{tabular}{|c|l|r|r|l|}
\hline No & Kelas Interval & Frekuensi & Persentase & \multicolumn{1}{|c|}{ Kategori } \\
\hline 1 & 60 ○ $\bar{X}$ & 0 & $0 \%$ & Sangat Positif \\
\hline 2 & 50 ○े $\bar{X}<60$ & 25 & $86,21 \%$ & Positif \\
\hline 3 & 40 ○ $\bar{X}<50$ & 4 & $13,79 \%$ & Ragu-ragu \\
\hline 4 & 30 ○े $\bar{X}<40$ & 0 & $0 \%$ & Negatif \\
\hline
\end{tabular}


ISSN 2089-8673

Jurnal Nasional Pendidikan Teknik Informatika (JANAPATI)

Volume 2, Nomor 1, Maret 2013

\begin{tabular}{|l|l|l|l|l|}
\hline 5 & $\bar{X}<30$ & 0 & $0 \%$ & Sangat Negatif \\
\hline
\end{tabular}

Respon siswa kelas XI Program Keahlian Multimedia di SMK Negeri 3 Singaraja terhadap pengembangan media audio visual Menerapkan Efek Khusus Pada Objek Produksi tersebar pada kategori sangat positif $0 \%$, positif $86,21 \%$, ragu-ragu $13,79 \%$, negatif $0 \%$ dan sangat negatif $0 \%$. Rata-rata skor respon siswa yaitu 52,86 sehingga respon siswa terhadap pengembangan media audio visual Menerapkan Efek Khusus Pada Objek Produksi dapat dikategorikan positif.

Persentase respon siswa terhadap pengembangan media audio visual Menerapkan Efek Khusus Pada Objek Produksi dapat disajikan pada gambar 4.

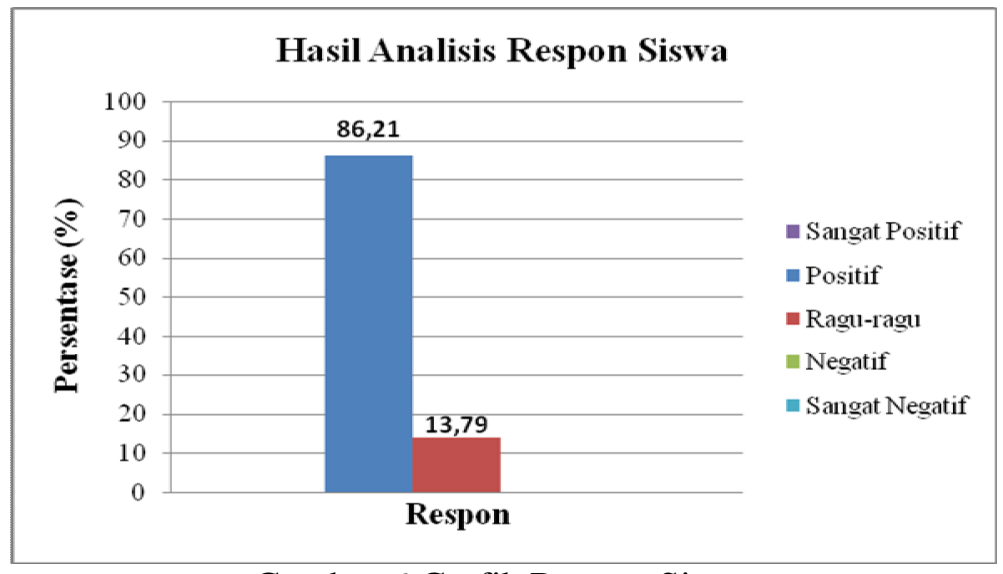

Gambar 6 Grafik Respon Siswa

Respon guru terhadap pengembangan media audio visual multimedia Menerapkan Efek Khusus Pada Objek Produksi dikumpulkan dengan menggunakan angket respon guru. Berdasarkan hasil analisis skor respon guru (terlampir pada lampiran 14). Rata-rata skor respon guru yaitu 51 sehingga respon guru terhadap pengembangan media audio visual Menerapkan Efek Khusus Pada Objek Produksi dapat dikategorikan positif.

\section{Penutup}

Berdasarkan hasil analisis data dan pembahasan pada penelitian ini, maka dapat diambil simpulan yaitu (1) Pengembangan media audio visual ini dimaksudkan untuk merancang dan mengimplementasikan media audio-visual pada mata diklat menerapkan efek khusus pada 


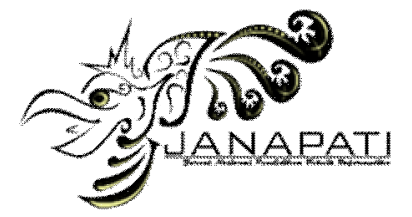

objek produksi berbasis project based learning untuk siswa kelas XII SMK Negeri 3 Singaraja, (2) Untuk mengetahui respon siswa dan guru mata diklat menerapkan efek khusus pada objek produksi, di kelas XII SMK Negeri 3 Singaraja terhadap pengembangan media audio-visual berbasis project based learning.

Berdasarkan pengamatan penulis, terdapat beberapa hal yang dapat dijadikan bahan pertimbangan untuk ditindak lanjuti diantaranya (1) Media Audio Visual Menerapkan Efek Khusus Pada Objek Produksi berbasis project hanya berupa video. Untuk pengembangan selanjutnya dapat dikemas dalam bentuk berbeda misal web, atau media interaktif lain. (2) Media audio visual ini hanya bersifat suplementer dan tidak bersifat komplementer sehingga dalam penggunaanya perlu didukung oleh sumber belajar lain yang relevan sehingga media audio visual ini dapat digunakan secara optimal. (3) Media audio visual berbasis project based learning yang berupa CD (compact disc) dikembangkan berdasarkan karakteristik siswa di SMK N 3 Singaraja kelas XII, sehingga bila digunakan pada siswa di SMK yang lain, pada kelas yang lain atau bila ditemukan kesalahan atau kelemahan yang perlu diperbaiki, maka produk pengembangan ini dipersilakan untuk direvisi seperlunya. 
ISSN 2089-8673

Jurnal Nasional Pendidikan Teknik Informatika (JANAPATI)

Volume 2, Nomor 1, Maret 2013

\section{DAFTAR PUSTAKA}

Ardhana, I W. 2002. ÒKonsep Penelitian Pengembangan dalam Bidang Pendidikan dan Pembelajaranò. Makalah Disampaikan pada Lokakarya Nasional Angkatan II Metodologi Penelitian Pengembangan Bidang Pendidikan dan Pembelajaran. Malang: Universitas Negeri Malang.

Astuti, Endang. 2011. Pengembangan Media Audiovisual (VCD) Sinematisasi Puisi Sebagai Media Pengajarana Apresiai Puisi Pada Siswa SMA Kelas X Sampel yang dipakai adalah siswa kelas X. Universitas Negeri Semarang. Tidak diterbitkan

Budiningsih, C.A. 2005. Belajar dan Pembelajaran. Jakarta: PT. Rineka Cipta.

Djatmiko, Istianto W. 2010. Pendidikan Vokasi dalam Perspektif Philosopher Tradisional. Jurnal. Fakultas Teknik Universitas Negeri Yogyakarta.

Ginanjar, Gigin. 2010. Penerapan Model Pembelajaran Berbasis Proyek (Project-Based Learning) sebagai upaya Meningkatkan Hasil Belajar Siswa. Skripsi FPTK UPI. Tidak diterbitkan

Kamdi, Waras. 2008. ñProject-Based Learning: Pendekatan Pembelajaran Inovatifò. Makalah Pelatihan Penyusunan Bahan Ajar Guru SMP dan SMA Kota Tarakan. Malang: Universitas Malang

Moeslichatoen R. 2004. Metode Pengajaran di Taman Kanak-kanak, Jakarta: Rineka Cipta.

Mualifah. 2010. Progresivisme Pendidikan John Dewey dalam Perspektif Pendidikan Islam. Jurnal. Fakultas Tarbiyah IAIN Sunan Ampel Surabaya.

Munadi, Yudhi. 2008. Media audio visual, Sebuah Pendekatan Baru, Ciputat: Gaung Persada Press.

Muslich Suyono, Masnur. 2009. Pengembangan Media audio visual Kosakata Berbasis Audio-Visual untuk Peningkatan Kompetensi Berbahasa Indonesia Anak Usia Dini. Jurnal Kependidikan Fakultas Sastra, Universitas Negeri Malang. Tidak diterbitkan

Noor Fajar, Rahmawati. 2010. Pembangunan Sistem Informasi Perpustakaan Pada Badan Koordinasi Survei Dan Pemetaan Nasional (Bakosurtanal) Berbasis Web. Tugas Akhir Program Keahlian Manajemen Informatika, Direktorat Program Diploma, Institut Pertanian Bogor. Tidak diterbitkan 
ISSN 2089-8673

Jurnal Nasional Pendidikan Teknik Informatika (JANAPATI)

Volume 2, Nomor 1, Maret 2013

Nurohman, Sabar. 2007. Pendekatan project based learning Sebagai Upaya Internalisasi Scientific Method Bagi Mahasiswa Calon Guru Fisika. Jurnal. FPMIPA UNY.

Rusdi Andi. 2008. ñModel Pengembangan Perangkat Pembelajaranò h www.scribd.com/doc/32195915/Model-an-Perangkat/. (diakses tangga November 2011).

Rusmana. 2011. Analisis Kemampuan Kognitif Siswa Sma Kelas X Dalam Praktikum Terintegrasi Audio Visual Pada Materi Pokok Larutann Elektrolit Dan Nonelektrolit. Skripsi FPTK UPI. Tidak diterbitkan

Santyasa, I W. 2006. ñMetodologi Penelitian Peningkatan Kualitas Pembelajaran (PPKP)ò. Makalah Disajikan dalam Pelatihan Para Dosen Undiksha tentang Penelitian Tindakan Kelas dan Penelitian untuk Peningkatan Kualitas Pembelajaran di Perguruan Tinggi. Singaraja: Nopember.

Santyasa, I W. 2007. ñLandasan Konseptual Media audio visualò. Makalah Disajikan dalam Workshop Media audio visual bagi Guru-Guru SMA Negeri Banjar Angkan, Undiksha, Klungkung 10 Januari 2007.

Santyasa, I W. 2009. ñMetode Penelitian Pengembangan Dan Teori Pengembangan Modulò. Makalah Disajikan dalam Pelatihan Bagi Para Guru TK, SD, SMP, SMA, dan SMK Tanggal 12-14 Januari 2009, Di Kecamatan Nusa Penida kabupaten Klungkung.

Sony Wirawati, Ketut. 2011. Pengembangan Media Audio-Visual Dengan Model Hannafin Dan Peck Dalam Mata Pelajaran Bahasa Inggris Pada Siswa Kelas VIII Semester 2 SMPN 7 Singaraja. Skripsi Teknologi Pendidikan, Universitas Ganesha, Singaraja. Tidak diterbitkan

Sudarma, I K. \& I M. Tegeh. 2007. ñPenelitian Pengembangan (Pengembangan ProdukProduk di Bidang Teknologi Pendidikan)ò. Makalah Disajikan dalam Pelatihan Penyusunan Proposal Penelitian Pengembangan di Jurusan Teknologi Pendidikan Undiksha, Undiksha, Singaraja Januari.

Sugiyono. 2008. ñMetode Penelitian Pendidikan Pendekatan Kuantitatif, Kualitatıt dan R \& Dò. Bandung: Alfabeta CV.

Sulaeman, Cecep. 2011. Pengaruh Penerapan Audio Visual Terhadap Hasil Belajar Dribbling Dalam Pembelajaran Sepak Bola. Skripsi FPTK UPI. Tidak diterbitkan 
ISSN 2089-8673

Jurnal Nasional Pendidikan Teknik Informatika (JANAPATI)

Volume 2, Nomor 1, Maret 2013

Sunarya, Ari. 2011. Perbandingan Media audio visual Audio Visual dan Tanpa Audio Visual terhadap Peningkatan Keterampilan Gerak Siswa dalam Pembelajaran Sepak Bola di SMA Kartika III-I Bandung. Skripsi FPTK UPI. Tidak diterbitkan

Supa Edi Putra, Kadek. 2011. Pengembangan Media audio visual Audiovisual Mengenal Rambu Lalu Lintas Jalan Di Sekitar Kita Pada Mata Pelajaran Bahasa Indonesia Untuk Siswa Kelas III Sekolah Dasar Negeri 2 Melinggih, Kecamatan Payangan Kabupaten Gianyar. Skripsi Teknologi Pendidikan, Universitas Ganesha, Singaraja. Tidak diterbitkan

Supriatna Dadang. 2007. ñKonsep Dasar Desain Pembelajaranò. Makalah disampaikan pada Diklat E-Training PPPPTK TK dan PLB. Pusat Pengembangan Dan Pemberdayaan Pendidik Dan Tenaga Kependidikan Taman Kanak K ${ }^{{ }^{m} \mathbf{r} r}$ Dan Pendidikan Luar Biasa. 